日本臨床麻酔学会第27 回大会パネルディスカッション

\title{
心臟麻酔の知識スタンダード \\ 術中モニターの適応と選択
}

国沢卓之*

[要旨] 心臓麻酔で必要とされるモニターは, 他の麻酔と比較して, 種類が多岐にわ たる. それぞれのモニターの適応と選択について議論することも重要だが, 加えて, これらの機器から正確な情報を得て, 臨床に反映させる必要がある. それぞれの機器 の特徵や原理を理解し, ピットフォールや弱点を把握したうえでモニターとして活用 することが大切である，心臓麻酔の術中モニターでは, 各領域に精通し, 多くの情報 を総合的に判断する必要がある. またTEEは, 最も有用なモニターの一つであり, 多くの情報を引き出すことが可能である．最終的には多くのモニタ一機器を十分に理 解し, TEE 有効活用することが求められる.

キーワード : 術中モニター, TEE

(日臨麻会誌 Vol.29 No.2, $143 \sim 151,2009$ )

はじめに

心臓麻酔に利用されるモニターは，標準的モニ夕 一から症例に応じて使用される特殊なモニターま で，数多く存在する(図1)。それぞれのモニターの 適応を考慮し選択するためには, 各モニターの原理 と功罪を理解する必要がある。またそれぞれの機器 をモニターとして有効に活用するためには, さらに 複合的な評価が必要となる。

\section{I モニターの分類}

1. 標準モニターと拡大モニター

心臓麻酔モニターの分類法として，すべての患者 に必要とされる標準モニターと, 症例に応じて必要
とされる拡大モニターとの分類がある ${ }^{1)}($ 表 1).

表 1 にあげたもののほかに, 静脈麻酔薬の効果部 位濃度 (effect site concentration : ESC), 運動誘発 電位 (motor evoked potential : MEP)などが拡大モ ニターに含まれる。

\section{2. 侵襲度}

各種モニターは，侵襲度に応じて，非侵襲モニ夕 一，低侵襲モニター，侵襲モニターに分類される (表2).

3. 目的別 21

麻酔深度, 臓器虚血, 循環, その他など, モニ夕 リングの目的別に分類される。多くのモニターは, 循環モニタリングが主目的であるが，いろいろな目 的別分類で重複する項目も少なくない. 


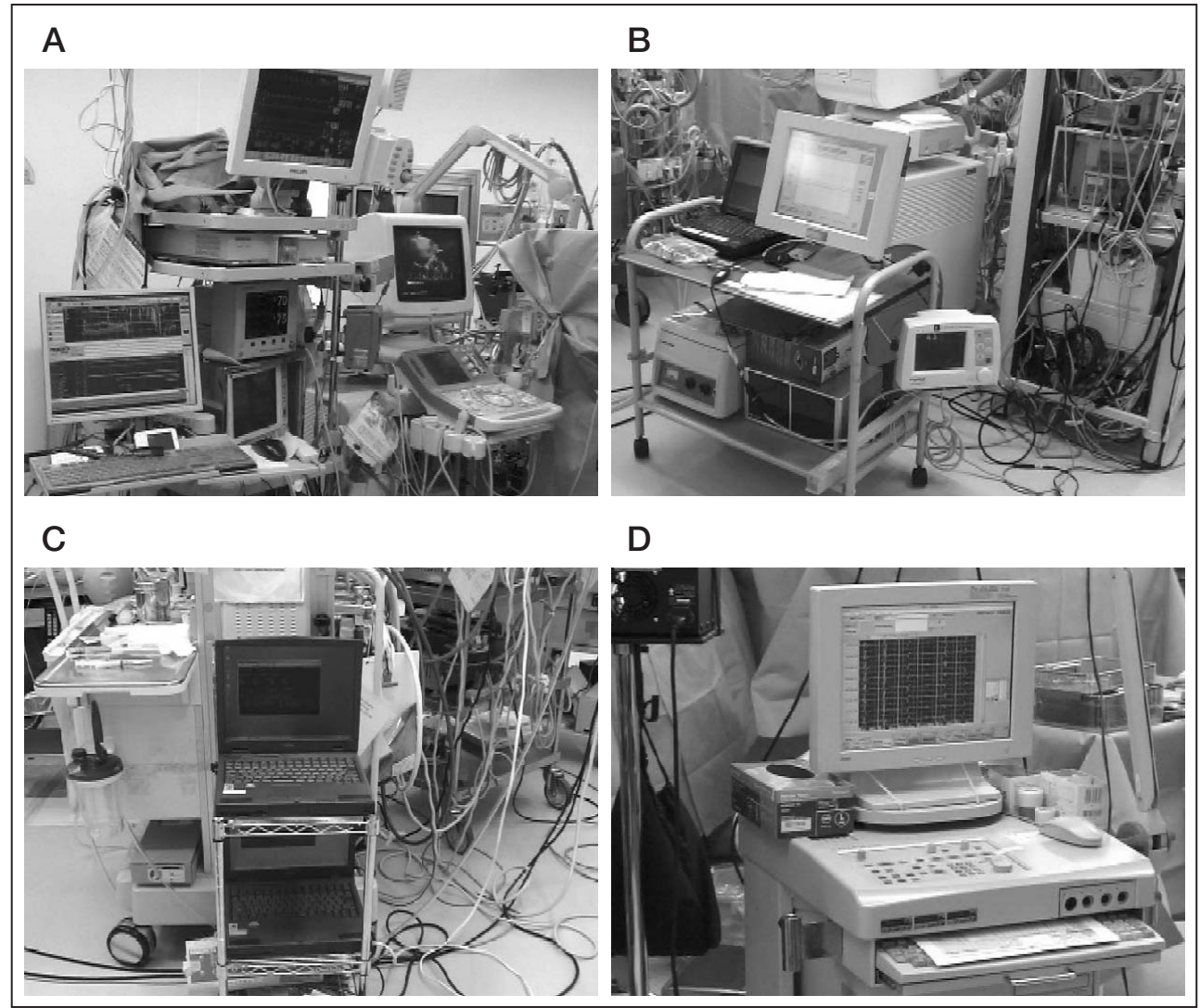

図1 心臓麻酔中のモニタリング風景

A：重要な経食道心エコー(TEE) は，患者に最も近い，操作しやすい場所に配置されてい る。プロポフォールは Diprifusor ${ }^{\mathrm{TM}}$ (アストラゼネカ社, 東京)を利用して効果部位濃 度がモニターされ，BIS モニタ $\mathrm{TM}$ (日本光電，東京）にて麻酔深度がモニターされてい る。画面中央には $\operatorname{INVOS}^{\mathrm{TM}}$ (エドワーズライフサイエンス社，東京）を使用して近赤 外分光法を利用した脳酸素飽和度をモニタリングしている。 その他，一般的な生体情 報, 肺動脈カテーテルを利用した, 圧, 心拍出量, 混合静脈血酸素飽和度などもモニ ターされている。

$\mathrm{B}$ ：左は PulseCO ${ }^{\mathrm{TM}}$ (ニプロ, 東京), 右は FloTrac ${ }^{\mathrm{TM}}$ (エドワーズライフサイエンス社, 東京)を利用して低侵襲連続的心拍出量測定を行っている.

C : 麻酔深度を一定にするため, 静脈麻酔薬はコンピュー夕制御下に target-controlled infusion systemを利用して投与を行っている。画面はレミフェンタニルとデクスメデ トミジンを投与中.

D : 脊髄虚血モニターとして, 運動誘発電位 (motor evoked potential : MEP)モニタリン グを行っている.

1)麻酔深度

静脈麻酔薬の ESC, 吸入麻酔ガス濃度, BIS モニ 夕 ${ }^{\mathrm{TM}}$ (日本光電, 東京)などが, 麻酔深度モニター に相当する.これらは心臓麻酔, 循環モニターとの 関与が少ないと考えられているが，後述の“モニ夕 リングのためのモニター”として重要となる。血圧
や心拍数も広義の麻酔深度モニターである.

2)臓器虚血モニター

脳酸素飽和度, 頸静脈酸素飽和度, 脊髄ドレナー ジ圧，MEPなどが該当する。心電図も心筋虚血の モニターとして利用される。 


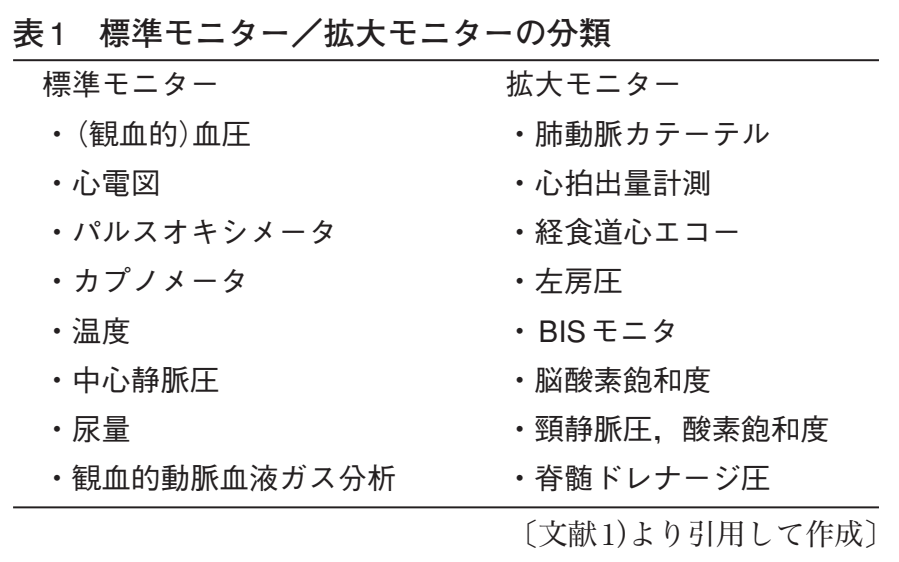

表2 侵襲度に応じたモニターの分類

\begin{tabular}{|c|c|c|}
\hline 非侵襲モニター & 低侵襲モニター & 侵襲モニター \\
\hline - 非観血的血圧 & - TEE & - 観血的動脈圧 \\
\hline • 心電図 & - 膀胱温, 直腸温 & - 中心静脈圧 \\
\hline - 経皮的酸素飽和度 & • BIS モニタ & ・肺動脈カテーテル \\
\hline ・カプノメータ & - 尿量 & ·左房圧 \\
\hline • 体表温 & & - 頸静脈圧, 酸素飽和度 \\
\hline - 脳酸素飽和度 & & ・腠髄ドレナージ圧 \\
\hline
\end{tabular}

3)循環モニター

各種圧 (血圧, 中心静脈圧, 肺動脈圧, 左房圧), 心拍数は, 循環モニターの代表である. 肺動脈カテ ーテル, TEE (経食道心エコー； transesophageal echocardiography）から得られる情報は非常に多い. 尿量, 体温も循環モニターとして重要である。カプ ノメータも肺血栓塞栓症などの際に，循環の指標と なりうる。

4) その他

呼吸, 体温, 腎機能, 神経機能のモニタリングを 目的として利用される機器, 項目がある.

\section{II モニターの適応と選択}

合併症が存在しない鼠径ヘルニア根治術に, 肺動 脈カテーテルやTEEをモニタリングとして利用す る麻酔科医は, 存在しないだろう。しかし冠動脈バ イパス手術では, 肺動脈カテーテルを挿入する症例 もあれば，挿入しない症例もあるであろう。モニ夕
リングの適応と選択は，以下によって判断される。

1. Risk-benefit ratio

侵襲モニターは，モニタリングから得られる情報 の有用性が，合併症を引き起こす潜在的危険性を上 回る必要がある。肺動脈カテーテルでは，これらの 評価が詳細に繰り返し検討されているため ${ }^{3)}$ ５)，参 考にすることが可能である。 また，TEEもガイドラ インとして症例ごとの有効性が報告されている ${ }^{6)}$. しかし, これら以外のモニターは, 症例に応じた功 罪を検討する必要があるため，絶対基準を決定する ことは容易ではない.

\section{Cost effectiveness}

非侵襲モニターであれば，すべての症例でモニタ リングを行ってよいということにはならない。患者 の outcomeまで含めた費用対効果が検討されるべき である．侵襲モニターも同様であるほほとんどのモ ニターで個別の検討がなされていないため, 費用対 効果の検討は今後の課題である. 


\section{表 3 観血的動脈圧測定の適応}

・大きな循環血液量変動, 出血を伴う大手術

・心肺バイパスを利用する手術

・大動脈手術

・頻回な動脈血ガス分析を必要とする肺疾患患者

- 心筋梗塞急性期, 不安定狭心症, 高度冠動脈疾患の患者

・高度心機能低下, 弁膜症患者

・ショック患者, 多臟器不全患者

・人為的低体温, 低血圧が施行される手技

・高度外傷

- 右心不全, 肺動脈疾患

・強心薬や大動脈内バルーンパンピングを必要とする患者

・電解質異常, 代謝障害により頻回の採血が必要な患者

・病的肥満など, 非観血的動脈圧測定が困難な患者

\section{表4 中心静脈カテーテル留置の適応}

・良心機能患者における大きな循環血液量変動, 出血を伴う大手術

・尿量評価が不確実, 不能な患者の血管内容量評価

・高度外傷

・坐位手術など空気塞栓の可能性が高い手術

・頻回な採血が必要な患者

・薬物投与

·末梢静脈路確保困難

・急速輸液必要症例

・完全非経口栄養

\section{3. モニター別適応 ${ }^{11}$}

1) 観血的動脈圧

血行動態が不安定な症例，非観血的血圧測定不能 例，頻回な動脈血ガス分析が必要な症例などは，絶 対適応になる。表 3 に適応を記載する。

2)中心静脈カテーテル留置

循環血液量変動を伴う症例などに加えて，輸液や 薬物療法，栄養療法などでも適応がある(表 4).

3)肺動脈カテーテル (PAC) 留置

肺動脈圧, 心拍出量, 混合静脈血酸素飽和度がほ ぼリアルタイムに測定・表示されるため，非常に有 用性の高いモニターとして以前より使用されてい る. 以前は多くの施設ですべての成人開心術が適応 とされていた ${ }^{2)}$. 肺動脈圧は右心機能，肺血管抵抗， 左房充満圧を反映し, 肺動脈楔入圧 (pulmonary
表 5 肺動脈カテーテル留置の適応

・循環血液量評価

• 心拍出量測定

- 血行動態測定

・呼吸, 酸素運搬能測定

〔文献1)より引用〕

artery wedge pressure ：PAWP)を測定することに より，左房充満圧をより直接的に測定することが可 能となる，右心系の圧が左心系の圧を正確に反映し ないことが多い開心術では7)，両者の心不全診断， 循環血液量評価に有用であるため，使用されてきた。 しかし，PAWPが前負荷の指標とならない ${ }^{8)}$, PAC が予後を改善しないなどの報告が続き ${ }^{3), 4)}$ ，最近で は，PACの有用性は否定するものではないが，使 用は限定されるべきであると考えられている5 TEEの有用性が広く浸透し，その使用に精通した麻 酔科医が増えたこともあいまって，PACの適応は 減少してきたと考えられる。表 5 は，Kaplan’s Cardiac Anesthesia ${ }^{1)}$ に記載されている適応である.

4) TEE

現在は，TEEの有用性は広く認知されている。 1996年に，患者の特徵，術式，施行環境などに基づ いて，有用性が3つのカテゴリーに分類された ${ }^{6)}$. この分類に従って適応が決定されるべきであるが, 急速な普及をとげた TEEでは，そのカテゴリー分 類，適応(表 6)などが大きく変化している可能性も ある。

5) MEP

下行大動脈手術において，前脊髄動脈の灌流障害 が起こりうる手術に適応となる。

\section{III モニター機器の評価を正確に行うために}

\section{1. モニタリングのためのモニター}

以前より，心臓麻酔は大量の麻薬が使用されるた め，詳細な麻酔深度をモニターすることが重要とさ れていなかった。しかし，MEPモニターを必要と する症例では，麻酔薬の調節が必要となるため，適 


\section{表6 TEEの適応}

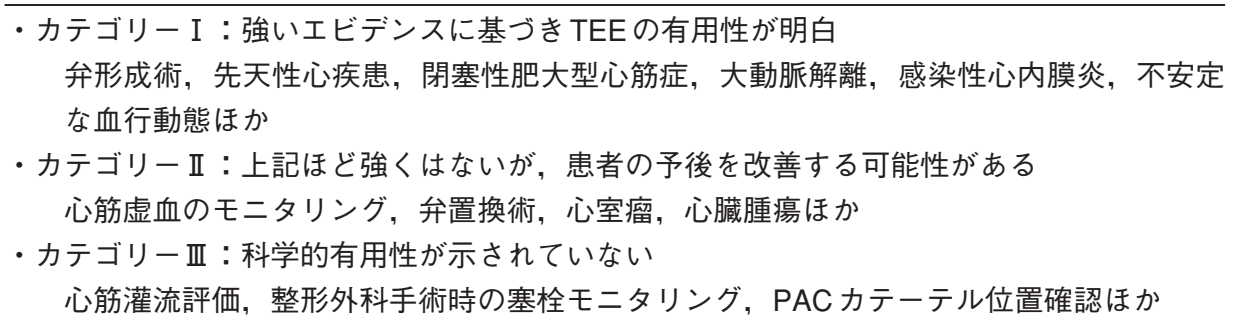

〔文献6)より引用〕

切な麻酔深度のモニター, 維持の重要性に着目され るようになった。つまり, 正確なモニタリングを行 つて麻酔深度を一定にすることで，MEPモニタリ ングを正確に行うことを可能にするため，モニタリ ングを行うためにモニターを活用する必要が生じた のである。

1) MEP と麻酔薬

多くの麻酔薬がMEPの振幅に影響を及ぼすた

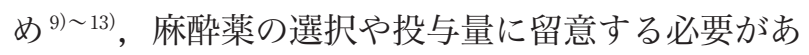
る。以前は，麻酔薬による振幅抑制が高度であり myogenic MEPの測定が容易ではなかったため, 硬 膜外に挿入された電極が導出電極として利用されて いた．刺激条件が検討され，トレインパルスが一般 化されることにより ${ }^{14)}$, myogenic MEPの測定が比 較的容易になり，プロポフォール，フェンタニルは 臨床的使用濃度では MEPの振幅や潜時に影響を及 ぼさないため ${ }^{15)}$, 臨床モニタリングとして普及した。 2)静脈麻酔薬と MEP

しかし，プロポフォール，フェンタニルいずれも 用量依存性に $\mathrm{MEP}$ 振幅を抑制するため ${ }^{13)}$ ，投与を 一定とするばかりでなく, 効果部位濃度を一定とす る麻酔管理が必要となった。すなわち持続投与量を 一定にするのでは, 投与時間とともに効果部位濃度 が上昇するため, TCI (target-controlled infusion) を利用して, 効果部位濃度を一定にすることが標準 となりつつあった。

3)衝撃の転機

ところが，2003年 Kakinohana ら ${ }^{16)}$ は，静脈麻酔
領域，心臓麻酤領域，神経機能モニタリングに衝撃 を与える報告を行った。 大腿動静脈送脱血による部 分体外循環中に, プロポフォールの血中濃度は上下 肢で解離し，持続投与を継続すると，上肢濃度が上 昇を続けるという内容であった。つまり，TCIを継 続することで, 効果部位濃度はどんどん上昇し続け るということになる。 MEPモニタリングを正確に 行うために, 効果部位濃度を一定にした投与法が, MEPモニタリングを正確に行うことを不可能にす る, 効果部位濃度を上昇させ続ける状態を引き起こ したのである。この状態への対処としては, BIS モ ニタ $\mathrm{TM}$ などを利用して，効果を指標とした調節を行 う必要があることとされた。

4)MEPモニタリングを行うためのモニター

麻酔薬濃度に影響されるMEP モタリングを行 うためには, 麻酔深度モニタリングを施行する必要 があることが上記から理解できる。また，動脈血炭 酸ガス分圧や体温, 血圧なども MEP振幅に影響を 及ぼすため，これらを一定にする必要がある ${ }^{17)}$. MEPモニタリングを正確に行うために，さまざま なモニタリングを行い, MEP振幅に影響を及ぼす 因子を一定にする必要がある。

5) MEP とレミフェンタニル

近年使用可能になったレミフェンタニルの登場 は，MEPモニタリングを行う麻酔薬にとって有用 であると思われる。MEP振幅に及ぼす影響がきわ めて低いことに加え ${ }^{12), 18)}$, 短時間作用性薬物である ため, 蓄積を認めない. 体外循環中の薬物動態や脊 
髄虚血に及ぼす影響を考慮する必要はあるものの， 有用性が高いことが推測される。

\section{2. 心拍出量測定}

心拍出量 (cardiac output：CO)の測定は，肺動脈 カテーテルを用いた方法が一般的である。しかし， TEEを利用して心拍出量を測定することも可能であ $3^{19), 20)}$. また，最近では低侵襲連続的心拍出量測定 器も登場している ${ }^{21)}$ 23). 同じ心拍出量測定でも, 測定機器と測定原理の違いで, 評価に留意する点が 異なる。

1)肺動脈カテーテル

ほぼリアルタイムに，継続的に表示され，簡便で 術者に依存しない安定性がある。測定モードに応じ て $0.5 〜 1$ 分ごとにデー夕更新を行う，90秒の平均 表示を行うなどの血行動態変動の反映が早いモード や，3〜 7分程度の平均が表示されるモードなどが 存在する ${ }^{24), 25)}$. カテーテル先端の位置や呼吸相に影 響を受( ${ }^{26)}$, 輸液負荷 ${ }^{27)}$ や復温期 ${ }^{28)}$ における急激 な温度変化にも影響されることと, 右心系の心拍出 量を測定していることとに留意する必要がある ${ }^{29}$.

2) TEE

測定したい部位の拍出量を直接測定できる利点が ある ${ }^{29)}$ ，例えば，経僧帽弁通過血液量, 経大動脈弁 通過血液量などに分けて測定が可能であるため，心 内シャント，弁逆流などが存在しても，意図する部 位の通過血液量を測定することが可能である ${ }^{29)}$ 。し かし，測定值を表示するためには，常に測定を繰り 返し行う必要があるため, 連続モニターとしては不 向きであり，測定を行っている際は，ほかのTEE 検査の施行を停止する必要がある。また，精度は術 者の技量によって異なるため, 繁用モニターとな りにくい.

3)低侵襲連続的心拍出量測定器

PulseCO ${ }^{\mathrm{TM}}$ (ニプロ社, 東京), FloTrac ${ }^{\mathrm{TM}}$ (エド ワーズライフサイエンス社, 東京), $\mathrm{PiCCO}^{\mathrm{TM}}$ (東機 貿, 東京)などが利用可能である。いずれも動脈圧 波形を解析してCO を算出する機器であるが，それ
ぞれ特徵を有している.PulseCO ${ }^{\mathrm{TM}}$ は $\mathrm{PiCCO}^{\mathrm{TM}}$ と同 様に 1 拍ごとに 1 回拍出量を表示させるため，急激 な変化に対する反映はきわめて早いが，心房細動な ぞでは，信頼性が低くなるが消耗品がない点は利点 である。使用前に較正が必要な点も， $\mathrm{PiCCO}^{\mathrm{TM}}$ と同 様であるが，TEEとの組み合わせで，より低侵襲で の利用が可能である ${ }^{30)}$. FloTrac ${ }^{\mathrm{TM}}$ は 20 秒間の平均 值を表示させている点で，他機種と異なる。特筆す べきは，較正が不必要である点である。 $\mathrm{PiCCO}^{\mathrm{TM}}$, PiCCOplus $^{\mathrm{TM}}$ は通常の動脈留置カテーテルでは測定 できない不都合が生じるが，肺血管外水分量 (extravascular lung water：EVLW)の測定，肺血 管透過性係数 (pulmonary vascular permeability index：PVPI)の算出を行うことにより，肺水腫の 指標を知り，原因検索を行うことが可能である。

\section{IV モニターとしての TEE}

TEEは，モニターとして多くの情報を提供しう る機器であるが，その特徵はほかのモニター機器と 異なっている。

1) 欠点

モニターが有用である条件の一つに，監視システ ムとしての機能がある。生体情報をリアルタイムに 表示，記録し異常発生時には警告を発することによ り，医療者に異常の発見を促す必要がある。しかし， TEE は，一部の機能の場合を除いて連続的に生体情 報を表示することは不可能であり，異常警告を発す ることはできない，TEEは，プローブを挿入してい るだけでは，なんら有益な情報を提供しない点を理 解し，手術の進行に応じて，TEEを操作し，情報を 引き出す必要がある。

2)卓越した拡大機能

モニターが患者の生体情報を表示し，警告を促す ものであるならば, TEEの機能はこれにとどまらず, 多くの情報を提供しうる。モニタリングの範疇であ れば，心機能のモニタリングが主な役割ではあるが， 術中イベント発生時の原因検索，診断を行うことが 


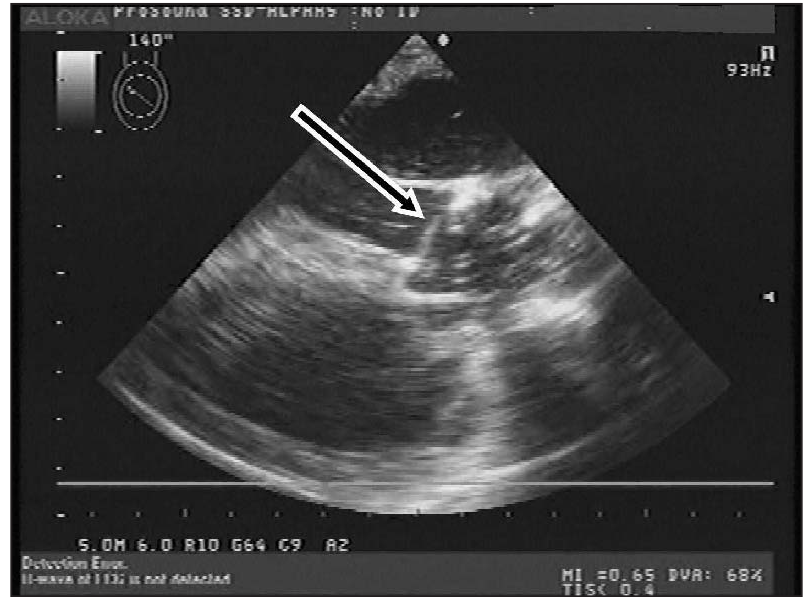

図2 TEE 診断により術式追加を行った症例のTEE 画像 術前診断では, 仮性動脈瘤による圧迫により大動脈 弁逆流 (AR)が生じているため圧迫解除によって AR が改善すると考えられていたが, 圧迫解除後も右冠 尖の高度逸脱 (矢印) を認め, 弁置換術が必要と判断 され大動脈弁置換術が追加された。

可能であり，手術操作のガイドとして利用すること も可能である。また，その診断能力は，術前，術中， 術後評価に利用され, Decision Making として術式 追加，決定に寄与しうる ${ }^{31)}$ (図2)。TEEを使いこな すことで, より詳細な情報を引き出し, 患者の状態 改善に寄与できる.

\section{最後に}

モニターは，電源を入れて，持続的に患者の状態 を表示し, 異常を警告してくれる有用な機器である。 しかし, 心臓麻酔に利用されるモニターは, 複雑で あり，モニターが正しい值を表示できるようにする ためにはさまざまな留意点を有する。虚血モニター は循環モニターに並んできわめて重要であるが，麻 酔を定常化させる必要がある。モニターとして特殊 なTEEは，自ら情報を発してくれるわけではない ので，その操作と評価に知識と技術が必要であるが, 一方で，その情報量の多さは，単なるモニターにと どまらず，術式決定に寄与しうる情報を得られる。

各種モニターの原理と落とし穴に精通すれば，そ の適応の判断と評価は容易で，得られた情報すべて
を総合的に評価し，患者の対応と治療に役立てるこ とが可能となる。

本稿の要旨は日本臨床麻酔学会第 27 回大会 $(2007$, 東京) パネルディスカッション(3)「心臓麻酔の知識 スタンダード」において発表した。

\section{参考文献}

1) Reich DL, Mittnacht A, London M, et al. : Monitoring of the heart and vascular system, Kaplan's Cardiac Anesthesia. Edited by Kaplan JA, et al. W.B. Saunders, Philadelphia, 2006, 385-436

2) Skeehan TM, Jopling M : 心臓手術患者のモニタリン グ，心臓手術の麻酔(第3版). Hensley FA ほか編，新見 能成監訳. メディカル・サイエンス・インターナショナ ル，東京，2004，113-157

3) Shah MR, Hasselblad V, Stevenson LW, et al. : Impact of the pulmonary artery catheter in critically ill patients : meta-analysis of randomized clinical trials. JAMA 294 : 1664-1670, 2005

4) Shah MR, Miller L : Use of pulmonary artery catheters in advanced heart failure. Curr Opin Cardiol 22 : 220224, 2007

5) Ranucci $\mathrm{M}$ : Which cardiac surgical patients can benefit from placement of a pulmonary artery catheter? Crit Care 10 (Suppl 3) : S6, 2006

6) Practice guidelines for perioperative transesophageal echocardiography. A report by the American Society of Anesthesiologists and the Society of Cardiovascular Anesthesiologists Task Force on Transesophageal Echocardiography. Anesthesiology 84 : 986-1006, 1996

7) Tuman KJ, Carroll GC, Ivankovich AD : Pitfalls in interpretation of pulmonary artery catheter data. J Cardiothorac Anesth 3 : 625-641, 1989

8) Kumar A, Anel R, Bunnell E, et al. : Pulmonary artery occlusion pressure and central venous pressure fail to predict ventricular filling volume, cardiac performance, or the response to volume infusion in normal subjects. Crit Care Med 32 : 691-699, 2004

9) Kalkman CJ, Drummond JC, Ribberink AA, et al. : Effects of propofol, etomidate, midazolam, and fentanyl on motor evoked responses to transcranial electrical or magnetic stimulation in humans. Anesthesiology 76 : 502-509, 1992

10) Zentner J, Albrecht T, Heusner D : Influence of halothane, enflurane, and isoflurane on motor evoked 
potentials. Neurosurgery $31: 298-305,1992$

11) Zentner J, Kiss I, Ebner A : Influence of anestheticsnitrous oxide in particular-on electromyographic response evoked by transcranial electrical stimulation of the cortex. Neurosurgery $24: 253-256,1989$

12) Scheufler KM, Zentner J : Total intravenous anesthesia for intraoperative monitoring of the motor pathways : an integral view combining clinical and experimental data. J Neurosurg 96 : 571-579, 2002

13) Scheufler KM, Zentner J : Motor-evoked potential facilitation during progressive cortical suppression by propofol. Anesth Analg 94 : 907-912, 2002

14) Taniguchi M, Cedzich C, Schramm J : Modification of cortical stimulation for motor evoked potentials under general anesthesia : technical description. Neurosurgery 32 : 219-226, 1993

15) Kunisawa T, Nagata O, Nomura M, et al. : A comparison of the absolute amplitude of motor evoked potentials among groups of patients with various concentrations of nitrous oxide. J Anesth 18 : 181-184, 2004

16) Kakinohana M, Miyata Y, Kawabata T, et al. : Bispectral index decreased to " 0 " in propofol anesthesia after a cross-clamping of descending thoracic aorta. Anesthesiology 99 : 1223-1225, 2003

17）高木治：誘発電位に与える影響, 誘発電位, 脳神経外科 麻酔ハンドブック．奥村福一郎編．南江堂，東京，1993， 64-66, 119-132

18）国沢卓之, 伊東民雄, 大町英世ほか：術中運動誘発電位 測定を施行した開頭手術に対しレミフェンタニル TCI を用いて麻酔管理を行った 1 症例。麻酔 57 ：467-470, 2008

19) Savino JS, Troianos CA, Aukburg S, et al. : Measurement of pulmonary blood flow with transesophageal two-dimensional and Doppler echocardiography. Anesthesiology 75 : 445-451, 1991

20) Gorcsan J 3rd, Kenny WM, Diana P, et al. : Transesophageal continuous-wave Doppler to evaluate mitral prosthetic stenosis. Am Heart J 121 : 911-914, 1991

21）筒井雅人，森知久，荒牧良彦ほか：連続的心拍出量モ二 夕ーPulseCO ${ }^{\mathrm{TM}}$ と $\mathrm{CCO}$ の比較。麻酔 53 ：929-933, 2004

22）小竹良文：FloTracとは一CCO モニターに代わるか？ 一。クリニカルエンジニアリング 18 ：63-69, 2007

23）片山勝之：連続心拍出量測定装置 $\mathrm{PiCCO}^{\circledR}$ ，心臓血管麻 酔マニュアル，真下節ほか編。中外医学社，東京，2004， $133-135$

24) Lazor MA, Pierce ET, Stanley GD, et al. : Evaluation of the accuracy and response time of STAT-mode continuous cardiac output. J Cardiothorac Vasc Anesth 11 : 432-436, 1997

25) Aranda M, Mihm FG, Garrett S, et al. : Continuous cardiac output catheters : delay in in vitro response time after controlled flow changes. Anesthesiology 89 : 1592 $-1595,1998$

26) Skeehan TM, Thys DM : 心臓手術患者のモニタリン グ，心藏手術の麻酔(第2版)。市瀬史ほか監訳. メディ カル・サイエンス・インターナショナル，東京，1997， $103-147$

27）西川俊昭：肺動脈カテーテル，心臟血管麻酔マニュアル。 真下節ほか編。中外医学社，東京，2004，148-151

28) Böttiger BW, Rauch H, Böhrer H, et al. : Continuous versus intermittent cardiac output measurement in cardiac surgical patients undergoing hypothermic cardiopulmonary bypass. J Cardiothorac Vasc Anesth 9 : 405-411, 1995

29）国沢卓之：TEEと危機管理一肺動脈カテーテルが異常 值を示したら一。 日臨麻会誌 28：583-589，2008

30）山岸昭夫，国沢卓之，長島道生ほか：連続的心拍出量乇 ニターPulseCO $\mathrm{TM}$ の有用性一経食道心エコー (TEE) に よる較正一。麻酔 2009 (in press)

31）野村実，杉野芳美，長沢千奈美ほか：経食道エコーによ る開心術の管理。臨麻 25：1111-1121，2001 


\title{
Indication for and Selection of Intraoperative Monitors
}

\author{
Takayuki KUNISAWA
}

Surgical Operation Department, Asahikawa Medical College Hospital

A larger variety of monitors are used for cardiac anesthesia than for other types of anesthesia. Discussion concerning the indication for and selection of monitors is needed, and it is also necessary to obtain accurate information from the monitors and use this information for clinical purposes. Each monitor must be used with an understanding of its characteristics and principles and an understanding of its pitfalls and disadvantages. A comprehensive judgment of the information obtained from intraoperative monitors for cardiac anesthesia based on a thorough knowledge of the functions of the monitors is required. A TEE monitor is one of the most useful monitors and can provide an abundance of information. A sufficient understanding of the various monitors used for cardiac anesthesia, including the TEE monitor, and effective utilization of TEE is required.

Key Words : Indication and selection, Intraoperative monitoring, TEE

The Journal of Japan Society for Clinical Anesthesia Vol.29 No.2, 2009 